\title{
PERAN DINAS PENDIDIKAN KABUPATEN SERANG DALAM MENGIMPLEMENTASIKAN PROGRAM WAJIB BELAJAR 9 (SEMBILAN) TAHUN UNTUK MEMENUHI HAK BELAJAR ANAK
}

\author{
Ade Millatus Sa'adiyyah ${ }^{1}$, Siti Kulsum ${ }^{2}$ \\ Universitas Banten Jaya \\ Serang, Indonesia \\ ade.millatus@gmail.com ${ }^{1}$, Sitiikulsum54@gmail.com²
}

\begin{abstract}
This study aims to determine the role of the Serang Regency Education Office in implementing the 9 (nine) year compulsory education program in Serang Banten Regency, to determine the obstacles faced by the Serang Regency Education Office in implementing the 9 (nine) year compulsory education program to fulfill their rights. learning children, and to find out the efforts made by the Serang District Education Office. This study used a descriptive qualitative research method with depiction of facts, data in the form of language expressions and appropriate and systematic interviews. The results of this study indicate that the role of the Serang Dalan district education office in implementing the 9 (nine) year compulsory education program to fulfill children's learning rights has carried out its main duties and functions, namely carrying out regional government affairs in the education sector. So it can be said that the role of the Serang District Education Office is very important in implementing the 9 (nine) year compulsory education program to fulfill children's learning rights.
\end{abstract}

Keywords: Serang District Education Office, 9 (nine) years compulsory education, fulfilling children's learning rights.

\section{PENDAHULUAN}

Manusia membutuhkan pendidikan dalam kehidupannya. Pendidikan merupakan proses pembelajaran untuk peserta didik dan guna mengubah tingkah laku anakanak didik agar menjadi manusia yang mampu hidup mandiri dan memiliki kekuatan spritual keagamaan, kecerdasan, kepribadian sebagai anggota masyarakat dalam lingkungan sekitar dimana individu itu berada. Sesuai yang di jelaskan oleh (Redja Mudyharjo:2016:11) dalam bukunya bahwa pendidikan merupakan usaha agar manusia dapat mengembangkan potensi dirinya melalui proses pembelajaran dan/atau cara lain yang dikenal dan diakui oleh masyarakat. Hal tersebut ditegaskan dalam UndangUndang No.20 tahun 2003 tentang sistem pendidikan nasional bahwa "pendidikan adalah usaha sadar dan terencana untuk mewujudkan suasana belajar dan proses pembelajaran agar peserta didik secara aktif mengembangkan potensi dirinya untuk memiliki kekuatan spiritual keagamaan, pengendalian diri, kecerdasan, akhlak mulia, serta keterampilan yang diperlukan dirinya, masyarakat, bangsa, dan negara". Jadi jelas bahwa pada dasarnya pendidikan adalah usaha manusia untuk dengan penuh tanggung jawab 
membimbing anak-anak didik menjadi kedewasaan.

Undang-Undang Dasar Republik Indonesia Tahun 1945 Pasal 31 ayat (1) menyebutkan bahwa setiap warga negara berhak mendapatkan pendidikan dan dalam ayat (3) menegaskan bahwa Pemerintah mengusahakan dan menyelenggarakan satu sistem pendidikan nasional yang meningkatkan keimannan dan ketaqwaaan serta akhlak mulia dalam rangka mencerdaskan kehidupan bangsa yang diatur dengan undang-undang. Untuk itu, seluruh komponen negara wajib mencerdaskan kehidupan bangsa yang merupakan salah satu tujuan negara Indonesia. Pada tahun 1998 saat mulai lahirnya Gerakan reformasi di Indonesia secara umum menuntut diterapkannya prinsip demokrasi, desetralisasi, keadilan, dan menjunjung tinggi hak asasi manusia dalam kehidupan berbangsa dan bernegara, begitupun dalam hal pendidikan.

Pelaksanaan Wajib Belajar pada hakekatnya merupakan upaya sistematis pemerintah untuk meningkatkan kualitas manusia indonesia, sehingga dapat berpartisipasi aktif dalam keseluruhan pembangunan nasional serta adaptif dalam penyerapan informasi ilmu pengetahuan dan teknologi (IPTEK) yang muaranya adalah pendekatan pada pencapaian tujuan pembangunan nasional, yaitu masyarakat yang adil makmur berdasarkan pancasila dan UUD 1945. Selain itu, program wajib belajar juga merupakan salah satu pembangunan skenario pendidikan yang dijangkaukan untuk perluasan dan pemerataan kesempatan belajar bagi setiap warga negara . Sebagaimana kewajiban tersebut dijelaskan dalam isi pasal 31 UUD 1945 ayat 1 yang mengatakan bahwa :

“setiap warga negara berhak mendapatkan pendidikan Menyadari betapa besar dan pentingnya peran pendidikan dalam meningkatakan dan pengembangan kualitas sumber daya manusia, pemerintah mengambil langkah antisipatif dengan pencanangan dan pemberlakuan program wajib belajar bagi setiap warga negara" .

Berdasarkan pasal 31 UUD 1945 ayat 1 tersebut diatas, setiap warga negar Indoonesia berhak mendapatkan pendidikan sesuai dengan minta dan bakatnya tanpa melihat status sosial, etnis dan juga agama yang dianut nya. Adanya pemerataan pendidikan diharapkan sumber daya manusia Indonesia yang berkualitas dapat diciptakan. Salah satu fungsi dari pendidikan adalah untuk menghilangkan segala kebodohan dan penderitaan rakyat, karena dengan modal ilmu pengetahuan dan keterampilan yang didapat dalam proses pendidikan diharapkan setiap warga negara mampu meningkatkan kualitas hidup dan daya saing nya di maa yang 
akan datang. Pada tahap awal pemerintah telah mencanangkan program wajib belajar 6 (enam) tahun yang pada dasarnya merupakan prasyarat umum bahwa setiap anak usia Sekolah Dasar (7-12 tahun ) harus dapat membaca, menulis dan berhitung. Melalui PP No. 28/1990 tentang Pendidikan Dasar menetapkam Program Wajib Belajar 9 (sembilan) tahun . Adapun prioritas kebijakan tersebut, antara lain : (1) penuntasan anak usia 7-12 tahun untuk Sekolah Dasar, (2) penuntasan anak usia 13-15 tahun untuk SLTP, dan pendidikan untuk semua. Program Wajib Belajar Dasar 9 (sembilan) Tahun diharapkan mampu mengantarkan manusia Indonesia pada pemikiran kompetensi Pendidikan Dasar, sebagai kompetensi minimal.

Kompetensi pendidikan dasar yang dimaksudkan mengacu pada kompetensi yang termuat dalam pasal UU No 20 Tahun 2003 yaitu kemampuan atau pengetahuan dan keterampilan dasar yang diperlukan untuk hidup dalam masyarakat serta untuk mengikuti pendidikan dasar yang lebih tinggi (pendidikan menengah) hal ini sesuai dengan unsur-unsur kompetensi pendidikan dasar yang dikuasai lulusan seperti yang diidentifikasi oleh The Internasional Development Research Center, meliputi : Kemampuan berkomunikasi ,
Kemampuan dasar berhitung

Pengetahuan dasar tentang negara, budaya dan sejarah, (4) memiliki pengetahuan dan keterampilan dasar dalam bidang kesehatan, gizi, mengurus rumah tangga dan memperbaiki kondisi , kerja dan (5) Kemampuan berpartisipasi secara aktif dalam masyarakat sebagai individu dan sebagai anggota masyarakat, memahami hak dan kewajibannya sebagai warga negara, bersikap dan berfikir kritis, serta dapat memanfaatkan yang didasari konsep "Pendidikan Dasar untuk Semua (Univesal Basic Education)", juga sejalan dengan piagam PBB tentang Hak Asasi Manusia, tentang Hak Anak, dan tentang Hak dan Kewajiban Anak. Wajib Belajar merupakan fondasi bagi pembangunan jenjang pendidikan lebih lanjut dan kemajuan peradaban bangsa khususnya dalam menghadapi tantangan dan Perkembangan zaman dan kompetisi tingkat global .

Dengan adanya Pendidikan diharapkan mampu mewujudkan masyarakat maju yang berwawasan luas dan modern. Dasar Wajib Belajar juga terdapat pada Pasal 34 halaman 18 adalah sebagai berikut :

(1) Setiap warga negara yang berusia 6 (Enam) tahun dapat mengikuti program wajib belajar.

(2) Pemerintah dan Pemerintah Derah menjamin terselenggaranya wajib 
belajar minimal pada jenjang pendidikan dasar tanpa memungut biaya.

(3) Wajib Belajar merupakan tanggung jawab negara yang diselenggarakan oleh lembaga pendidikan Pemerintah, Pemerintah Daerah, dan masyarakat.

(4) Ketentuan mengenai wajib belajar sebagaimana dimaksud dalam ayat (1), ayat (2), dan ayat (3) diatur lebih lanjut dengan Peraturan Pemerintah.

Disisi lain, pelaksanaan wajib belajar baik 6 (enam) tahun maupun 9 (sembilan) tahun secara umum bertujuan untuk :

1. Memberikan kesempatan setiap warga negara tingkat minimal SD dan SMP atau yang sederajat,

2. Setiap warga negara dapat mengembangkan dirinya lebih lanjut yang akhirnya mampu memilih dan mendapatkan pekerjaan yang sesuai dengan potensi yang dimiliki,

3. Setiap warga negara mampu berperan serta jalani kehidupan bermasyarakat, berbangsa dan bernegara, dan

4. Memberikan jalan kepada siswa untuk melanjutkan pendidikan ketingkat yang lebih tinggi.

Sejalan dengan kebijakan nasional dalam rangka membangun kehidupan masyarakat yang berakhlak mulia, cerdas, kreatif, dan mandiri berdasarkan imptak dan iptek. Tujuan pelaksanaan wajib belajar pendidikan dasar 9 (sembilan) tahun, yang ingin dicapai oleh Dinas Pendidikan dan Kebudayaan Kabupaten Serang, adalah sesuai dengan tujuan pendidikan nasional seperti yang tertuang dalam Undang-Undang Sistem Pendidikan Nasional, Bab II Pasal 3 menjelaskan bahwa, mengembangkan peserta didik agar menjadi manusia yang beriman dan bertakwa kepada Tuhan Yang Maha Esa, berakhlak mulia, sehat, berilmu, cakap, kreatif, mandiri, demokrasi dan bertanggung jawab.

Sejalan dengan perkembangan zaman saat ini ilmu pengetahuan dan teknologi, perbaikan kegiatan belajar dan mengajar harus diupayakan secara maksimal agar mutu pendidikan meningkat, hal ini perlu dilakukan karena majunya pendidikan membawa dampak meluas terhadap pemikiran manusia dalam berbagai bidang, sehingga setiap generasi muda harus belajar banyak untuk menjadi manusia terdidik sesuai dengan tuntunan zaman. Berdasarkan sumber data verifikasi PDSPK , Juli 2019 angka putus sekolah di Kabupaten Serang Banten sebanyak 89 siswa di tingkat Sekolah Dasar dan sebanyak 152 siswa ditingkat Sekolah Menengah Pertama, serta terdapat siswa yang mengulang di Kabupaten Serang Banten sebanyak 1.571 siswa ditingkat Sekolah Dasar, dan 192 siswa yang mengulang di tingkat Sekolah Menengah 
Pertama. Peningkatan sumber daya manusia yang dilakukan lewat pendidikan tidak luput dari beberapa hambatan, sebagaimana dijelaskan (Redja:2016) bahwa terdapat beberapa hambatan dalam menjalankan wajib belajar diantaranya terdapat faktor lingkungan fisik maupun non fisik penuntasan keberhasilan wajib belajar 9 (sembilan) tahun dapat di pengaruhi oleh dua faktor yaitu faktor internal dan faktor eksternal siswa. Faktor internal, meliputi kemampuan, minat, motivasi, nilai-nilai dan sikap, ekspetasi (harapan) Faktor eksternal meliputi latar belakang ekonomi orangtua, persepsi orangtua tentang pendidikan, jarak sekolah dari rumah, hubungan guru-murid.

Dampak yang ditimbulkan dari adanya beberapa faktor diatas dapat mempengaruhi minat anak untuk tetap menuntut ilmu, anak menjadi kesulitan untuk sekolah dikarnakan tidak ada biaya, anak justru ikut orangtua nya bekerja dengan ikut mengumpulkan barang bekas dari pinggir-pinggir jalan di jam yang seharusnya digunakan untuk menuntut ilmu disekolah.

Berdasarkan penelitian awal yang peneliti lakukan di dinas kabupaten serang. Peneliti ingin mengetahui mengenai “ Peran Dinas Pendidikan Kabupaten Serang Dalam Mengimplementasikan Program Wajib Belajar 9 (Sembilan)
Tahun Untuk Memenuhi Hak Belajar Anak”

\section{METODE PENELITIAN}

Penelitian ini bertujuan untuk mendapatkan gambaran dan informasi yang lebih jelas, lengkap serta memungkinkan dan mudah bagi peneliti untuk melakukan penelitian observasi. Oleh karena itu, penulis menetapkan lokasi penelitian adalah tempat dimana penelitian akan dilakukan. Lokasi penelitian terletak di Dinas Pendidikan Kabupaten Serang Banten.

Adapun waktu yang dilakukan pada penelitian ini yaitu pada bulan JuniAgustus 2020. Subjek merupakan suatu yang penting dalam penelitian, subjek penelitian harus disiapkan sebelum peneliti siap untuk mengumpulkan data. Subjek penelitian dapat berupa benda, hal atau orang (Arikunto, 2007 : 26). Peneliti menentukan subjek penelitian berdasarkan permaslahan yang akan di teliti tentang Peran Dinas Pendidikan Kabupaten Serang Dalam Mengimplementasikan Program Wajib Belajar 9 (Sembilan) Tahun Untuk Memenuhi Hak Belajar Anak. Maka, subjek penelitiannya yaitu Kepala Sub Bagian Pembinaan dan Evaluasi, Kepala Seksi Peserta Didik dan Pengembangan Karakter SMP, Kepala Bidang Pembinaan SD, Masyarakat, Orangtua, dan Anak di daerah Kabupaten Serang Banten. 
Metode yang digunakan dalam penelitian ini adalah penelitian kualitatif. Sesuai yang dijelaskan oleh (Sugiyono:2016) bahwa penelitian kualitatif adalah penelitian yang menggambarkan, mendeskripsikan dengan apa yang dilihat, didengar, dirasakan, dan ditanyakan.

Pengumpulan data yang akan peneliti lakukan dengan cara pencarian data yang ada di lapangan dan melakukan tindakan di lapangan. Adapun teknik pengumpulan data yang akan dilakukan peneliti pada rencana penelitian ini adalah :

1. Observasi, dalam praktiknya di lapangan peneliti melakukan pengamatan berkaitan dengan Peran Dinas Pendidikan Kabupaten Serang Dalam mengimplementasikan wajib belajar 9 (sembilan) tahun untuk memenuhi hak belajar anak, hambatanhambatan yang dihadapi Dinas Pendidikan Kabupaten Serang dalam mengimplementasilan program wajib belajar 9 (sembilan) tahun untuk memenuhi hak belajar anak, serta upaya yang dilakukan oleh Dinas Pendidikan Kabupaten Serang dalam mengimplementasikan program wajib belajar 9 (sembilan) tahun untuk memenuhi hak belajar anak.

2. Wawancara, Peneliti akan melakukan wawancara ke dinas pendidikan Kabupaten Serang Banten, masyarakat, orangtua dan anak yang putus sekolah. Adapun yang peneliti wawancarai dalam penelitian ini adalah Kepala Sub Bagian Perencanaan dan Evaluasi, Kepala seksi peserta didik dan pengembangan karakter SMP, Kepala bidang pembinaan SD, Masyarakat, Orangtua dan Anak putus sekolah.

3. Dokumentasi, Peneliti akan melakukan dokumentasi untuk mencari data mengenai hal-hal yang berkaitan dengan variabel yang berupa data neraca pendidikan daerah Kabupaten Serang Banten tahun 2019 serta foto dokumentasi saat wawancara yang dapat mendukung tim dalam penelitian (Sugiyono:2017:240).

Dalam penelitian ini penelilti akan menggunakan teknik analisis data kualitatif dari Miles dan Huberman dalam Sugiyono (2016) yaitu "analysis as consisting of three flows activity: data reducing, data display, and drawing conclusion or verification. Artinya tiga tahapan yang akan dilakukan dalam menganalisis data kualitatif yaitu dengan menggunakan mereduksi data, menampilkan/penyajian data dan menggambarkan kesimpulan atau membuat verifikasi. 
HASIL PENELITIAN DAN

PEMBAHASAN

1. Bagaimana Peran Dinas Pendidikan Kabupaten Serang Dalam Mengimplementasikan Program Wajib Belajar 9 (sembilan ) Tahun di Kabupaten Serang.

Dinas Pendidikan untuk wilayah Kabupaten Serang Banten merupakan instansi pemerintah yang bertanggung jawab tentang semua hal yang berkaitan dengan pendidikan di wilayahnya. Salah satu tugas nya adalah melaksanakan urusan pemerintahan Kabupaten Serang bidang pendidikan berdasarkan azas otonomi dan tugas pembantuan, serta melaksanakan tugas-tugas lain berkaitan dengan pendidikan yang diberikan oleh Walikota/Bupati sesuai dengan bidang tugas nya. Melalui kantor Dinas Pendidikan ini, pemerintah daerah bidang pendidikan melakukan tugasnya pada wilayah kerjanya. Tugas tersebut mencakup pembantuan urusan pendidikan, pengawasan, penyusunan, program pendidikan daerahnya, menyusun strategi, perumusan kebijakan pendidikan, hingga memberikan layanan umum dalam hal pendidikan.

Pengertian Wajib Belajar 9 (Sembilan) Tahun terdapat dalam buku
Undang-undang RI Nomor 20 Tahun 2003 Tentang Sisdiknas \& Peraturanperaturan RI Tahun 2015 Tentang Standar Pendidikan Nasional Pendidikan Serta Wajib Belajar (hal: 18). Wajib Belajar berdasarkan Pasal 34 adalah sebagai berikut :

a. Setiap warga negara yang berusia 6 (enam) tahun dapat mengikuti program wajib belajar.

b. Pemerintah dan Pemerintah Daerah menjamin terselenggaranya wajib belajar minimal pada jenjang pendidikan dasar tanpa memungut biaya .

c. Wajib belajar merupakan tanggung jawab negara yang diselenggarakan oleh lembaga pendidikan Pemerintah, Pemerintah Daerah, dan Masyarakat.

d. Ketentuan mengenai wajib belajar sebagaimana dimaksud dalam ayat (1), (2), dan (3) di atur lebih lanjut dengan Peraturan Pemerintah.

Wajib belajar adalah kewajiban anak usia 7-12 tahun untuk memperoleh pendidikan dasar (dalam rangka mencerdaskan kehidupan bangsa) (Kamus Besar Bahasa Indonesia, 2007:1226). Wajib belajar sekolah lanjutan tingkat pertama adalah kewajiban bagi setiap Warga Negara Indonesia yang telah menamatkan 
Sekolah Dasar atau yang sederajatbdengan batas usia 13-15 tahun untuk mengikuti pendidikan sekolah lanjutan tingkat pertama atau yang sederajat samapai tamat. (Dirjen Dikdasmen, 1992 : 28).

Berdasarkan hasil pengamatan yang dilakukan oleh peneliti dilapangan bahwa Peran Dinas Pendidikan Kabupaten Serang sangat berperan penting dalam mengimplementasikan program wajib belajar 9 (sembilan) tahun hal ini dapat di lihat, bahwa Dinas Pendidikan Kabupaten Serang telah meningkatkan kuantitas dan kualitas sarana prasarana dan fasilitas pelayanan dasar, seperti pembenahan ruang kelas yang rusak, adanya sarana lapangan olahraga dan pelayanan dasar mengenai pendidikan, membuat zona percontohan Satuan Pendidikan Dasar dan Menengah, seperti adanya sekolah yang dibuat sebagai zona percontohan untuk penerapan kurikulum baru jika didapati tidak ada masalah dan berjalan sesuai dengan harapan maka sekolah lain pun akan menerapkan kurikulum yang sama, kemudian Dinas Pendidikan Kabupaten Serang meningkatkan mutu dan kualitas tenaga pendidik seperti , jika sekolah tersebut bermutu dengan pencapaian yang baik maka dapat di pasti kan akan melahirkan anak-anak yang bermutu juga, dan meningkatkan kualitas guru dengan mengadakan uji kemampuan guru (UKG) dimana guru di uji atau di tes kemampuannya . Hal tersebut juga diungkapkan oleh Bapak Cahyono ketika peneliti melakukan wawancara yaitu "Ada beberapa indikator yang harus kita lihat seberapa jauh tingkat pencapaian pendidikan di Kabupaten Serang. Yang pertama dari 8 indikator standar pendidikan, bisa di lihat dari profil Dinas Pendidi Kabupaten Serang sampaimana tingkat pendidikan di Kabupaten Serang, jika kita bandingkan dengan beberapa daerah khususnya di Provinsi Banten saja ada 8 Kabupaten/Kota, Kabupaten Serang memang belum bisa berada diatas di lihat dari kompetensi standar lulusan Kabupaten Serang berada di posisi ke 7 dari hasil indikator Ujian Nasional meskipun tahun ini tidak ada Ujian Nasional tetapi beberapa tahun kebelakang Kabupaten Serang berada di posisi ke 7 dari perolehan hasil Ujian Nasional berada di atas Kabupaten Lebak. Yang kedua adanya standar kompetensi tenaga pendidik kompetensi guru seperti yang kita tahu di lihat dari UKG (Uji Kompetensi Guru) di lihat pada tahun 2015 di Kabupaten Serang berada di posisi 6 diantara 8 Kabupaten/kota, nah dari 2 
indikator ini saja sudah dapat di lihat kondisi pendidikan Kabupaten Serang khususnya pendidikan dasar di Kabupaten Serang ini memang masih banyak pekerjaan-pekerjaan yang harus dikerjakan bagaimana meningkatkan pendidikan di Kabupaten Serang, kemudian dari sisi sarana dan prasarana, memang banyak terutama dari sisi pemerataan seluruh sekolah/seluruh satuan pendidikan, memperoleh sarana dan prasarana yang lengkap dengan memberikan bantuan dari dana pemerintah agar semua fasilitas sekolah memadai". Dinas Pendidikan Kabupaten Serang telah melakukan kinerjanya dengan baik. Hal ini serupa dengan dijelaskan oleh Muzayyin (2009:69) bahwasannya "Pendidikan bagi umat manusia merupakan sistem dan cara meningkatkan kualitas hidup dalam segala bidang. Dalam sejarah hidup manusia di muka bumi ini, hampir tidak ada kelompok manusia yang tidak menggunakan pendidikan sebagai pembudayaan dan peningkatan kualitasnya, sekalipun dalam kelompok masyarakat primitif salah satu sarana yang efektif yaitu membina dan mengembangkan manusia dalam masyarakat adalah pendidikan yang teratur, berdaya guna, dan berhasil guna. Pendidikan di semua level pendidikan haruslah diorganisasikan atau di kelola secara rapi, efektif dan efisien melalui sistem dan metode yang benar sehingga menghasilkan mutu pendidikan yang diharapkan. (Muzayyin 2009:69).

\section{Hambatan-hambatan apa saja yang} di hadapi oleh Dinas Pendidikan Kabupaten Serang Dalam Mengimplementasikan Program Wajib Belajar 9 ( Sembilan) Tahun Untuk Memenuhi Hak Belajar Anak.

Berdasarkan hasil penelitian yang telah di lakukan hambatan-hambatan yang di hadapi dalam mewujudkan program wajib belajar tidak hanya di Kabupaten Serang pasti mempunyai kendala-kendala di Kabupaten Serang sendiri masih perlu kerja keras untuk mewujudkan program wajib belajar 9 (sembilan) tahun ini bisa sukses, karena tanpa peran masyarakat di dalam memahami dan menyadarkan dirinya sendiri, dan menyadarkan anak-anaknya bahwa belajar itu penting, dan ketersediaan dana untuk mengcover mayarakat-masyarakat yang memang secara ekonomi lemah perlu dukunagan dana dari pemerintah, maka berikut ini dapat di lihat beberapa permasalahan yang dihadapi oleh Dinas Pendidikan dalam 
mengimplementasikan program wajib belajar 9 (sembilan) tahun untuk memenuhi hak belajar anak :

a. Faktor kesadaran orang tua, dimana faktor yang doniman bagi pendidikan anak terutama untuk menyekolahkan, setelah lulus Sekolah Dasar ke jenjang SLTP. Biasanya bagi masyarakat petani desa yang mayoritas petani, mereka dapat mengolah lahannya dengan baik tanpa membutuhkan atau melalui pendidikan yang tinggi. Ijazah tidak dianggap penting dan bukan kebutuhan hidup untuk masa depan anaknya, pendidikan orang tua juga akan sangat mempengaruhi pola untuk mendidik anak. Sebab hal ini akan berhubungan persepsi orang tua terhadap sekolah itu sendiri yang di hubungkan dengan pengalaman individu dalam mengamati sekolah dan kaitanya dengan kejadian sehari-hari di lingkungannya. Masyarakat Pada umumnya menilai bahwa kecakapan baca tulis standar lulusan SD digunakan untuk mengubah standar hidup. Gambaran kehidupan semacam ini dapat membentuk sebagian masyarakat untuk kurang menghargai sekolah dan lulusannya, dalam kondisi seperti ini beberapa kemungkinan bisa terjadi, seperti tidak menyekolahkan anaknya, memberhentikan anaknya sebelum tamat, atau tidak mau tahu tentang bangunan atau keberadaan sekolah dilingkungannya.

b. Faktor ekonomi, dimana kemiskinan biasanya akan mempengaruhi aspek-aspek lain termasuk pendidikan. Kita tidak bisa menutup mata bahwa angka kemiskinan masih menduduki presentase tinggi. Hal inilah yang menjadi masalah besar dalam mewujudkan wajib belajar 9 (sembilan) tahun untuk memenuhi hak belajar anak. Seperti yang di jelaskan oleh Engkos Kosasih (2018:336) bahwasannya :

"pada umum nya pembahasan tentang ekonomi tidak lepas dari pengeluaran jumlah rata-rata rumah tangga perbulan. Asumsi ini bila dijelaskan bahwa semakin tinggi rata-rata pengeluaran rumah tangga semakin rendah kemungkinan anak untuk meninggalkan sekolah (semakin tinggi rata-rata konsumsi semakin rendah drop out). Mulyanto meyatakan bahwa Besarnya pengeluaran untuk konsumsi memberikan arti bahwa 
komponen pengeluaran konsumsi lebih penting mereflesikan status ekonomi rumah tangga (Mulyanto Sumardi, 1986: 74). Sementara kondisi ekonomi seperti ini disebabkan berbagai faktor, di antaranya orang tua tidak mempunyai pekerjaan tetap, perceraian dan hanya mengandalkan diri sebagai buruh tani. Hal selaras juga dikemukakan oleh

Gerungan (1998: 182) bahwa: Hubungan orang tua dengan anaknya dalam status sosialekonomi serba cukup dan kurang mengalami tekanan-tekanan fundamental seperti dalam memperoleh nafkah hidupnya yang memadai. Hal ini dapat disimpulkan bahwa Orang tua dapat mencurahkan perhatian yang lebih mendalam kepada pendidikan anaknya apabila ia tidak disulitkan dengan perkara kebutuhankebutuhan primer kehidupan manusia."

3. Bagaimana upaya-upaya yang di lakukan Dinas Pendidikan Kabupaten Serang Dalam Mengimplementasikan Program Wajib Belajar 9 (sembilan) Tahun
Untuk Memenuhi Hak Belajar Anak.

Berdasarkan hasil observasi yang dilakukan oleh peneliti bahwa Peran Dinas Pendidikan Kabupaten Serang dalam mengimplementasikan program wajib belajar 9 (sembilan) tahun sudah berjalan dengan baik, dimana dapat dilihat bahwa siswa mendapatkan kesempatan belajar ,seperti halnya pemerintah sudah membangun program sekolah SATAP (Sekolah Satu Atap) yang merupakan pemecahan masalah jika terdapati sekolah yang mempunyai jarak tempuh yang jauh dengan keadaan gegrafis yang cukup sulit maka pemerintah mendirikan sekolah yang tempatnya sama dengan sekolah sebelum nya, kemudian siswa yang berprestasi akan mendapatkan beasiswa seperti, beasiswa tunjangan untuk melanjutkan pendidikan, dan bentuk beasiswa lainnya yang menunjang pendidikan nya ,hal ini juga di ungkapkan oleh Bapak Cahyono ketika wawancara "Upaya-upaya yang dapat dilakukan agar program wajib belajar 9 (sembilan) tahun dapat berjalan dengan optimal, yang dapat dilakukan oleh Dinas Pendidikan Kabupaten Serang sebagaimana anak-anak tidak putus sekolah yaitu dengan menyadarkan anak-anak untuk tetap semangat belajar 
dan meneruskan pendidikan sampai setinggi-tinggi nya, memberikan dukungan dari segi pendanaan, kepada masyarakat yang perekonomian nya lemah agar dapat melanjutkan pendidikan, dan pemerataan sarana dan prasarana ,memberikan kesempatan belajar dengan membangun Sekolah Satu Atap (SATAP) dan Sekolah Paket (paket A, B dan C)".

Hal ini di perkuat dengan hasil wawancara bersama Kepala Bidang Pembinaan SD Amar Ma'ruf ,S.Pd.,M.Pd yang menyatakan bahwasannya :

"mengenai sosialisasi program wajib belajar 9 tahun itu sangat penting, kemudian mengenai sosialisasi sebenarnya Dinas Pendidikan sendiri sudah mempunyai perda wajib belajar 9 tahun, kepada masyarakat melalui Kepala Sekolah, Pengawas, dan Penilik seluruh anak Kabupaten Serang melalui orangtua anak tidak boleh putus sekolah."

Mengingat begitu pentingnya peran dan misi pendidikan dalam kehidupan berbangsa dan bernegara tidaklah berlebihan jika pemerinta menggantungkan harapan kepada dunia pendidikan. Maju dan mundurnya sebuah negara dapat dilihat dari sektor pendidikan warga negaranya. Oleh sebab itu, pemerintah mencanangkan wajib belajar 9 tahun bagi warga negara Indonesia berusia 7 sampai dengan 15 tahun. Program wajib belajar pendidikan dasar 9 tahun merupakan perwujudan amanat pembukaan UUD 1945 dalam rangka mencerdaskan kehidupan bangsa serta pasal 31 UUD 1945 yang menyatakan (1) Tiap-tiap warga negara berhak mendapat pengajaran dan

Pemerintah mengusahakan dan menyelenggarakan satu sistem pengajaran nasional yang diatur dengan undang-undang.

\section{KESIMPULAN}

1. Peran Dinas Pendidikan dalam mengimplementasikan program wajib belajar 9 (sembilan) tahun di Kabupaten Serang Banten, semenjak ada UU No 23 tahun 2011 kewenangan SLTA berada di bawah kewenangan Pemerintah Provinsi, sehingga kewenangan Dinas Pendidikan Kabupaten Serang/Kota hanya mengampu jenjang Pendidikan PAUD, SD dan SMP kemudian ada juga yang disebut dengan kesetaraan ada paket A,B dan C. Dinas Pendidikan sendiri ikut serta meluncurkan program pemerintah dalam mensukseskan program wajib belajar 9 (sembilan) tahun yang dicanangkan oleh pemerintah seperti memerikan 
beasiswa kepada siswa yang tergolong keluarga prasejahtera serta memberi dukungan serta motivasi kepada siswa agar tetap semangat dalam belajar dan sekolah dengan memberikan beasiswa kepada mereka yang berprestasi.

2. Hambatan-hambatan yang dihadapi Dinas Pendidikan Kabupaten Serang Banten diantara adalah kurangnya kesadaran dari orang tua dan diri sendiri, dimana kesadaran orang tua merupakan faktor yang dominan bagi pendidikan anak terutama untuk menyekolahkan anak, setelah lulus Selokah Dasar ke jenjang SLTA, kemudian kesadaran diri dari anak juga merupakan salah satu faktor yang dapat menghambat anak untuk melanjutkan sekolah nya ke jenjang yang lebih tinggi, serta faktor ekonomi , kemiskinan biasanya akan mempengaruhi aspek-aspek lain termasuk aspek pendidikan. Kita tidak bisa menutup mata bahwa angka kemiskinan masih menduduki presentasi tinggi. Hal inilah yang menjadi masalah besar dalam mewujudkan wajib belajar 9 (sembilan) tahun untuk memenuhi hak belajar anak, maka dari itu Dinas Pendidkan masih bekerja keras dalam mewujudkan program wajib belajar 9 (sembilan) tahun untuk memenuhi hak belajar anak di Kabupaten Serang Banten.

3. Upaya-upaya Dinas Pendidikan dalam mengimplementasikan program wajib belajar 9 (sembilan) tahun untuk memenuhi hak belajar anak yaitu dengan memberikan dukungan dari segi pendanaan kepada masyarakat yang prasejahtera seperti ikut serta dalam meluncurkan program pemerintah dengan memberikan beasiswa bagi siswa yang tergolong prasejahtera, memberikan dukungan dari segi memberikan beasiswa bagi siswa yang berprestasi agar anak tetap semangat dalam belajar dan bersekolah, melakukan pemerataan sarana dan prsana yang dapat menunjang jalannya kegiatan belajar mengajar, memberikan kesempatan belajar seperti mendirikan sekolah satu atap agar anak-anak yang memiliki ketebatasan transportasi dalam mengenyam pendidikan, kemudian mendirikan sekolah paket agar anak yang mempunyai keterbatasan waktu untuk sekolah justru di pakai untuk membantu orang tuanya bekerja dengan membangun sekolah paket $\mathrm{A}$ untuk SD, paket B untuk SMP dan paket C untuk SMA, serta menyadarkan anak-anak untuk tetap belajar dan meneruskan sekolah sampai setinggi-tinggi nya dengan 
mensosialisasikan melalui kerja sama dengan Kecamatan, Kepala Sekolah, Pengawas, Penilik, serta peran orang tua sejatinya jika dilakukan secara berkala dan saling berkordinasi maka apa yang di cita-citakan dapat berjalan secara optimal.

\section{DAFTAR PUSTAKA}

Redja Mudyaharjo (2016) Pengantar

Pendidikan. Bandung : Citra UmbaraUndang-Undang Ri Nomor 20 Tahun 2003 Tentang Sisdiknas \&Peraturan Pemerintah Ri Tahun 2015 Tentang Standar Nasional Pendidikan Sub Wajib Belajar

Sugiyono. 2016. Metode Penelitian Kuantitatif, Kualitatif Dan $R$ \& D. bandung. Alfabeta.

Arikunto, Suharsimi. 2013. Prosedur Penelitian. Jakarta. PT. Rineka Cipta Muzayyin Arifin, (2009) Kapita Selekta Pendidikan Islam. Jakarta :Bumi Aksara Cet.4

\section{Sumber skripsi:}

Taupik, (2011) Pelaksanaan Wajib Belajar 9 Tahun di Kecamatan Keritang Kabupaten Indragiri Hilir. Riau : Universitas Islam Negeri Sultan Syarif Kasim.

\section{Jurnal:}

Engkos Kosasih. (2018). Partisipatory Action Research (Par) Implementasi Kebijakan Wajib Belajar Pendidikan Sembilan Tahun di Kabupaten Serang. JIPAGS, Volume 2 Nomor 2 Juli 2018. 323-347. 